\title{
IMPACT OF DEMOGRAPHIC CHANGES ON AGRICULTURAL DEVELOPMENT IN MONTENEGRO
}

\author{
Aleksandra Despotović1, Miljan Joksimović2, Miomir Jovanović ${ }^{3}$
}

\begin{abstract}
Number of citizens in a country represents its primary production potential. Montenegro has significant natural resources for rural development. However, many problems follow rural development, and one of those problems is the demographic problem.

The paper analyzes demographic changes in Montenegro by its regions, as well as gender and age structure of the population in the period 1948-2011. Statistical methods (tabular views, percentage accounts, base and chain indexes and graphs) are used in the preparation of the paper. They are used as "desk research" method and method of comparison. The aim of the paper is to highlight the trend of demographic changes and their impact on the development of agriculture in Montenegro, in the period 1948-2011. The obtained results indicate negative consequences of demographic changes (population and deagrarisation), as well as the reduction of the agricultural population. They have also influenced the decrease of agricultural production and the formation of unfavourable environment for its improvement. One of the greatest consequences of deagrarisation is the lack of manpower. Montenegrin agriculture is characterized by the aging of the rural population and significantly lower average level of education.
\end{abstract}

Key words: demographic changes, rural development, structure, agriculture.

JEL: $Q 10, Q 16$

\section{Introduction}

Montenegro is located in South-Eastern Europe on the Balkan Peninsula, covering an area

1 Aleksandra Despotović, Ph.D., Associate Professor, University of Montenegro, Biotechnical Faculty Podgorica, Department for Agro Economic Research, Mihalila Lalića Street no. 15, 81000 Podgorica, Montenegro, Phone: +38269306330, E-mail: alexd@t-com.me

2 Miljan Joksimović, MSc, Assistant, University of Montenegro, Biotechnical Faculty Podgorica, Department for Agro Economic Research, Mihalila Lalića Street no. 15, Podgorica, Montenegro, Phone: +38268438625, E-mail: miljanj@ac.me

3 Miomir Jovanović, Ph.D., Associate Professor University of Montenegro, Biotechnical Faculty Podgorica, Department for Agro Economic Research, Mihalila Lalića Street no. 15, 81000 Podgorica, Montenegro, Phone: +38269320623, E-mail: miomirj@ac.me

EP 2015 (62) 3 (613-625) 
of $13,812 \mathrm{~km}^{2}$ and having 620,029 inhabitants. Population density of 46 inhabitants per $\mathrm{km}^{2}$ puts Montenegro among the countries with the lowest population density. Compared with countries in the region, density is lower than in Bosnia and Herzegovina (75), Croatia (56.56), Serbia (88.4), Slovenia (102), Macedonia (83) (World Bank, 2014). Urban population accounts to $63 \%$ of the total population in Montenegro. According to the census from 2011 - 620,029 people live in Montenegro out of which 1.3\% is more than in 2003 year in which the previous census was carried out. In regard to 2011, the highest number of inhabitants is in the central region 293,509 (47.3\%), then in the northern region $-177,837$ $(28.7 \%)$, while the coastal region is the region with the lowest population density $-148,683$ $(24.0 \%)$. In the inter-census period, it was evident that there was a reduction in the population in the northern region, while the central and coastal recorded an increase. Above mentioned changes are caused by the natural migration of population, as distinct migratory flows go from north to central and coastal parts of the country. In addition to the aforementioned changes, changes in structure of the population were also recorded - primarily due to age, which may be an important factor of influence on the further development of the region. These changes and trends have had a negative impact on the development of agricultural production, which is almost entirely based on family house holdings. Lack of labour force as the main key driver of development represents a significant drawback for further development. According to one of the principles of traditional peasant economy, impact on agricultural production in the house holds depends on the available number of hands, i.e. the number of household members who are able to work and engage in the field of agriculture (Mendras, 1986). The youth in rural areas have not asked for its economic emancipation due to improving of economic situation of agriculture but instead they went away from it (Bandin, 2011). Turbulent structural changes have occurred in the villages of Montenegro after the end of the World War II. The population is a significant factor in rural development, because the existing population recruits a new workforce, and also because the population is a carrier of needs, as a factor of consumption, i.e. production (Pejanović, 2010). Main reasons for depopulation were: industrialization, urbanization, expropriation and agrarian reform. Unfavourable position of agriculture and private households, as well as more favourable conditions of life in the city caused population escaping from villages and agriculture (Čikić, 2012). In this respect, an example of Montenegro was not isolated. Processes of leaving the rural areas also occured in some other countries of former Yugoslavia, as well as in some countries of the world. Thus, e.g. in Croatia between 1961 and 1971, more than half a million of people have left rural areas. Almost, all rural settlements have been affected by demographic discharge, and a great part of them lost over half of the population in a few decades. Permanent erosion of generation, longterm reduction in fertility and aging raise a number of difficult solvable existential and other problems (Nejašmić, 2012).

Today, some countries in the world have extremely aggravated physical and demographic imbalances, such as the Southeast of Canada, Northeast US, Chinese Plain etc. (MASA, 2010). 


\section{Material and method of work}

The paper analyzes demographic changes in Montenegro by its regions, as well as gender and age structure of the population in the period 1948-2011. The focus is on the causes of the "rural exodus" and its implications on the development of agriculture. The official data of the Statistical Office of Montenegro (MONSTAT) were used in the preparation of the paper. Also, in order to present the current situation on the field as well as its comparison with the official statistics, data used was obtained from survey carried out on 60 households in the municipality of Podgorica, Bijelo Polje and Kolašin. The data in this paper is gathered by years and displayed by each year in which censuses in Montenegro were conducted (19482011). In displaying the data, the statistical tables, line and area chart were used. With regard to relative numbers of the structure, the participation of population of some regions in the total population was shown, as well as the participation of male and female population in the total population. Dynamic statistical analysis is applied, namely, the method of calculation of basic and chain indices. A "desk research" method is used, as well as the comparison method. The survey was carried out on the 60 households in the municipalities of Pljevlja, Bijelo Polje and Kolašin. The paper aims to highlight demographic discharge of rural areas, which depending on the political-geographic, traffic and other position is expressed in distinctive intensity at different places.

\section{Research results}

In the $20^{\text {th }}$ century, population of Montenegro was under the influence of wars, which resulted in the decrease of the population. The total population in 1921 was 311,341 . In period 1921-1931 there was an intense demographic growth, thus in 1931 the population increased by $15.6 \%$ (projection of the population of Montenegro to 2060 with the structural analysis of the population of Montenegro). The period after 1945 represents a milestone in the development of socio-economic relations in Montenegro. Participation of Montenegrin population on the total population of the former Yugoslavia ranged from $2.4 \%$ according to the Census from 1948 to $2.6 \%$ according to the Census from 1991. The largest increase in population of Montenegro was in the period between 1948 and 1953, and it was the highest growing rate in the former Yugoslavia. The increase, among other things, was due to the relatively high birth rate and permanent reduction in mortality (Vujošević, 1990). (Graph 1.) shows the change of total population of Montenegro in the period 1921-2001. 
Graph 1. Change of total population of Montenegro in the period 1921-2011

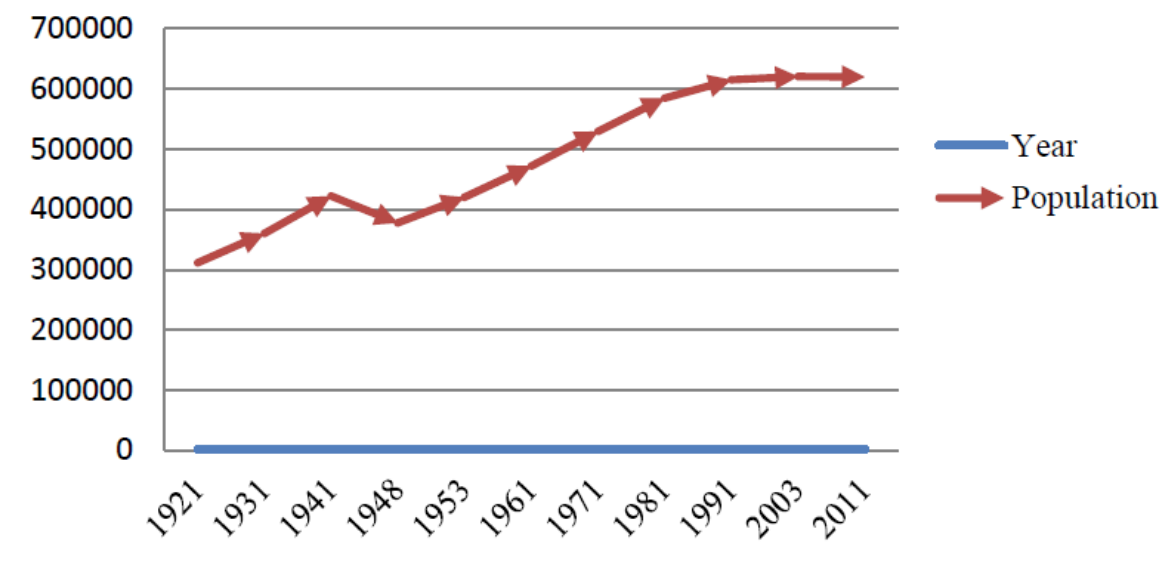

Source: MONSTAT, 2008

Table 1 shows the changes in population according to the base and chain indexes. Calculation of the authors was made on the basis of available statistical data in the publication "Demographic changes in Montenegro since the mid-20" perspective to 2050 “, (MONSTAT, 2011).

Table 1. Change of total number of citizens of Montenegro according to the base and chain indexes, 1921-2011.

\begin{tabular}{|c|c|c|}
\hline Year & Base index $\mathbf{1 9 2 1}=\mathbf{1 0 0}$ & Chain index \\
\hline $\mathbf{1 9 2 1}$ & 100 & - \\
\hline $\mathbf{1 9 3 1}$ & 115.64 & 115.64 \\
\hline $\mathbf{1 9 4 1}$ & 135.54 & 117.21 \\
\hline $\mathbf{1 9 4 8}$ & 121.19 & 89.41 \\
\hline $\mathbf{1 9 5 3}$ & 134.87 & 111.29 \\
\hline $\mathbf{1 9 6 1}$ & 151.60 & 112.40 \\
\hline $\mathbf{1 9 7 1}$ & 170.10 & 112.21 \\
\hline $\mathbf{1 9 8 1}$ & 187.68 & 110.33 \\
\hline $\mathbf{1 9 9 1}$ & 197.54 & 105.26 \\
\hline $\mathbf{2 0 0 3}$ & 199.19 & 100.83 \\
\hline $\mathbf{2 0 1 1}$ & 199.15 & 99.98 \\
\hline
\end{tabular}

Source: Calculation of the corresponding author according to the data from MONSTAT, $2011 \mathrm{~b}$

According to the conducted census, total population of Montenegro recorded a change in growth. On the basis of the calculated base index which took the year 1921 as the base year, the highest growth was in 2003 (99.19\%) in comparison to 1921. Chain indexes show that in the post-war period, the highest growth was in 1953 compared to the previous census from 1948, as well as in 1961 in the comparison to the census from 1953. In the subsequent period, it began to stagnate, i.e. it began to decline. These changes are immanent in societies that are rapidly industrialized and urbanized 
(Vujošević, 1990). In the reporting period regional differences could be recognized. (Graph 2.) shows the movement of the population by region.

Graph 2. Change of total population on Montenegro by regions, 1948-2011

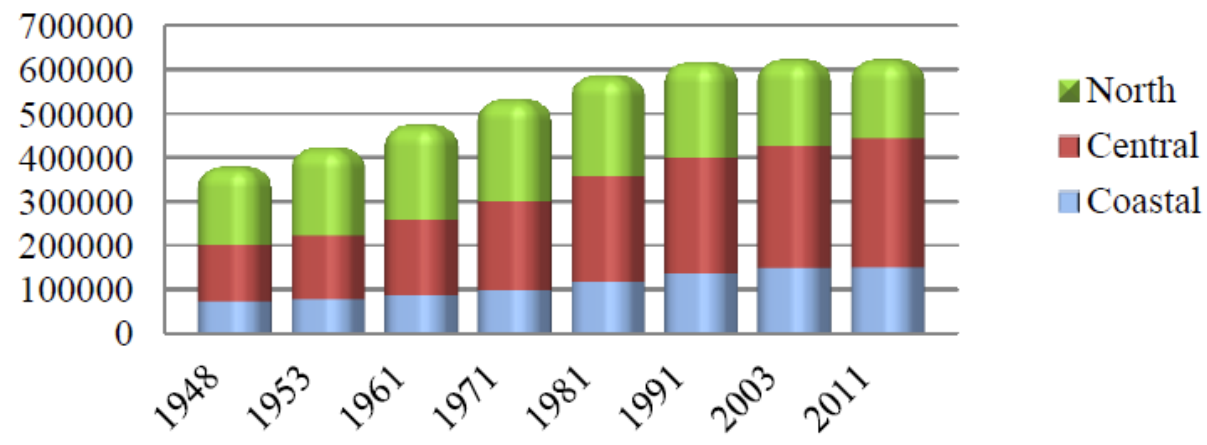

Source: MONSTAT, 2012

Table 2. shows the total population changes by regions according to the base and chain indices, as well as the percentage participation of the population of some regions in the total population of Montenegro. During the calculation of the base indexes, 1948 was determinate as the base year.

Table 2. Changes of total population changes by regions, percentage participation (\%), base and chain indices

\begin{tabular}{|c|c|c|c|c|c|c|c|c|c|}
\hline \multirow[b]{3}{*}{ Year } & \multicolumn{9}{|c|}{ R E G I O N S } \\
\hline & \multicolumn{3}{|c|}{ Coastal } & \multicolumn{2}{|c|}{ Central } & \multicolumn{4}{|c|}{ NORTH } \\
\hline & 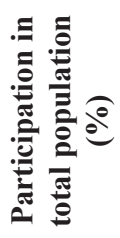 & $\begin{array}{l}\text { Base } \\
\text { index }\end{array}$ & $\begin{array}{l}\text { Chain } \\
\text { index }\end{array}$ & 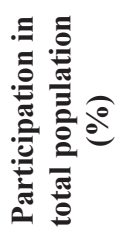 & $\begin{array}{l}\text { Base } \\
\text { index }\end{array}$ & $\begin{array}{l}\text { Chain } \\
\text { index }\end{array}$ & 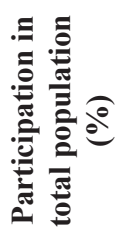 & $\begin{array}{l}\text { Base } \\
\text { index }\end{array}$ & $\begin{array}{l}\text { Chain } \\
\text { index }\end{array}$ \\
\hline 1948 & 18.5 & 100 & - & 34.2 & 100 & - & 47.3 & 100 & - \\
\hline 1953 & 18.1 & 97.84 & 97.84 & 34.6 & 101.17 & 101.17 & 47.3 & 100 & 100 \\
\hline 1961 & 17.7 & 95.68 & 97.79 & 36.1 & 105.56 & 104.34 & 46.2 & 97.67 & 97.67 \\
\hline 1971 & 18.3 & 98.92 & 103.39 & 38.3 & 111.99 & 106.09 & 43.4 & 91.75 & 93.94 \\
\hline 1981 & 19.8 & 107.03 & 108.20 & 41.0 & 119.88 & 107.05 & 39.2 & 82.88 & 90.32 \\
\hline 1991 & 21.9 & 118.38 & 110.61 & 42.6 & 124.56 & 103.90 & 35.5 & 75.05 & 90.56 \\
\hline 2003 & 23.5 & 127.03 & 107.31 & 45.1 & 131.87 & 105.87 & 31.4 & 66.38 & 88.45 \\
\hline 2011 & 24.0 & 129.73 & 102.13 & 47.3 & 138.30 & 104.88 & 28.7 & 60.68 & 91.40 \\
\hline
\end{tabular}

Source: Calculation of the corresponding author according to the data, MONSTAT (2008) 
According to the calculate percentage of the participation of population by regions, it could be seen that participation of coastal and central region has been growing since the census from 1981, while the participation of population of north region has been decreasing in the total population of Montenegro. This change resulted in a slower pace of development of agriculture. This is because, in the northern region, there is a significant area of meadows and pastures, which are a prerequisite for the development of livestock production, for which this region has a relative advantage. The structural area of land in Montenegro is covered by perennial meadows accounted for $37.39 \%$, while pastures account for $62.61 \%$. Livestock farming was one of the major occupations in the northern area of Montenegro, which has also influenced on the development of psychological and physical characteristics of people in those areas (Cvijić, 1966). Total number of households by areas of perennial meadows and pastures is 43,142, covering an area of 210,182 ha. The average area per household is 4,87 ha (perennial meadows and pastures) - (Structure of agricultural holdings - Used land, Agricultural Census, 2010). Calculated base indexes indicate that in 2011 in comparison to the based year of 1948, population in the coastal region increased by $29.73 \%$, the central by $38.30 \%$, while in the north it was reduced by $39.92 \%$. Chain indices show the changes from one census to another. In the coastal region in 1991 there was an increase in population by $10.61 \%$ compared to 1981 , in the central by $3.90 \%$; while in the north it decreased by about $10 \%$. The abovementioned has contributed to uneven regional development. Northern region (mainly rural) represents more than $50 \%$ of the country, but it has less than third of the total population. On the other hand, almost one-quarter of the population in Montenegro covers over $10 \%$ of the territory of Montenegro. These trends of population changes are not in line with the long term goal of Montenegro to develop as an agricultural country, bearing in mind primarily the development of livestock farming, fruit growing and crop husbandry in the north region.

In the context of demographic changes which appeared after 1945, it is important to point out the changes in the age and gender structure of the population. The gender structure of settlers depended on the type of migration. Women are more numerous among settlers who participate in local, internal migration, while men are more numerous in case of external primarily economically motivated migration. The results of the Census conducted in Montenegro, in the period from 1948-2011, showed that the female population outnumbered the men. Table 3. shows the total population by gender, as well as its structure.

Table 3. Total population by gender and age structure in Montenegro 1948-2011

\begin{tabular}{|c|c|c|c|c|c|}
\hline \multirow{2}{*}{ Year of census } & \multirow{2}{*}{ Total } & \multirow{2}{*}{ Male } & \multirow{2}{*}{ Female } & \multicolumn{2}{|c|}{$\begin{array}{c}\text { Participation in total } \\
\text { population (\%) }\end{array}$} \\
\cline { 5 - 6 } & & & & male & female \\
\hline $\mathbf{1 9 4 8}$ & 377,305 & 178,078 & 199,111 & 47.2 & 52.8 \\
\hline $\mathbf{1 9 5 3}$ & 419,905 & 201,718 & 218,155 & 48.0 & 52.0 \\
\hline $\mathbf{1 9 6 1}$ & 471,994 & 229,274 & 242,620 & 48.6 & 51.4 \\
\hline $\mathbf{1 9 7 1}$ & 529,604 & 259,209 & 270,395 & 48.9 & 51.1 \\
\hline $\mathbf{1 9 8 1}$ & 584,310 & 289,740 & 294,570 & 49.6 & 50.4 \\
\hline $\mathbf{1 9 9 1}$ & 615,035 & 305,931 & 309,104 & 49.7 & 50.3 \\
\hline
\end{tabular}




\begin{tabular}{|c|c|c|c|c|c|}
\hline \multirow{2}{*}{ Year of census } & \multirow{2}{*}{ Total } & \multirow{2}{*}{ Male } & \multirow{2}{*}{ Female } & \multicolumn{2}{|c|}{$\begin{array}{c}\text { Participation in total } \\
\text { population (\%) }\end{array}$} \\
\cline { 5 - 6 } & & & & male & female \\
\hline $\mathbf{2 0 0 3}$ & 620,145 & 312,068 & 321,917 & 49.2 & 50.8 \\
\hline $\mathbf{2 0 1 1}$ & 620,029 & 306,236 & 313,793 & 49.4 & 50.6 \\
\hline
\end{tabular}

Source: MONSTAT, 2008

In the reporting period, the participation of women in the total population is higher in relation to the participation of men. A phenomenon that manifests through a number of women in relation to the number of men is present as demographic regularity in almost all European countries, regardless of their demographic characteristics and social circumstances (Šobot, 2012). The changes that occurred in the period from 1948 to 1991 led to the balancing of gender structure of the population, which had been disturbed due to the World War II. However, although women have a greater participation in the total population compared to men, if some other indicators are observed, the following can be concluded: employment of women in agriculture in Montenegro takes a small part of their total employment (less than 4\%), while women make up to one-third of labour force. Main reasons for low interest of women to stay in rural communities are: women are rarely owners of the property and they are rarely in a position of holder of family households. According to the 2010 Census of Agriculture, women make up only $12.87 \%$ of holders of family holdings. Of a total number of 48,824 of holders of family agricultural house holdings - most holders $(16,228)$ are in the age group over 65 and over, with a participation of 33.24\% (2010 Census of Agriculture, Structure of agricultural holdings). Surveys data conducted on 60 households in the municipalities of Pljevlja, Bijelo Polje and Kolašin almost entirely correspond to the results of the Census of Agriculture. Nevertheless, $86.67 \%$ of holders of households were men, and $13.33 \%$ of holders were women (Joksimović, 2014).

Migration changes have also affected on the changes in the age structure of the population in Montenegro, which took place in the direction of demographic aging. This is primarily reflected in the increased participation of old or reduction or decrease in young people in the total population. Table 4. shows the population by age groups. Table 4. shows population by age groups.

Table 4. Population by big age groups in Montenegro, 1953-2003

\begin{tabular}{|c|c|c|c|c|c|c|}
\hline \multirow{2}{*}{ Age group } & $\mathbf{1 9 5 3}$ & $\mathbf{1 9 6 1}$ & $\mathbf{1 9 7 1}$ & $\mathbf{1 9 8 1}$ & $\mathbf{1 9 9 1}$ & $\mathbf{2 0 0 3}$ \\
\cline { 2 - 7 } & \multicolumn{7}{|c|}{ Number of citizens } \\
\hline Total & 419,873 & 471,894 & 529,604 & 584,310 & 615,035 & 633,985 \\
\hline $\mathbf{0 - 1 4}$ & 149,144 & 171,658 & 169,139 & 160,546 & 155,458 & 131,883 \\
\hline $\mathbf{1 5 - 6 4}$ & 239,781 & 266,514 & 317,417 & 373,406 & 402,754 & 421,256 \\
\hline $\mathbf{6 5}+$ & 30,930 & 33,440 & 40,417 & 48,020 & 50,603 & 75,156 \\
\hline $\mathbf{8 0}+$ & 5,972 & 7,088 & 8,322 & 9,366 & 11,215 & 10,087 \\
\hline
\end{tabular}

Source: MONSTAT, 2008 
Table 5. Participation of some age groups in the total population (\%) 1953-2003

\begin{tabular}{|c|c|c|c|c|c|c|}
\hline \multirow{2}{*}{ Age group } & $\mathbf{1 9 5 3}$ & $\mathbf{1 9 6 1}$ & $\mathbf{1 9 7 1}$ & $\mathbf{1 9 8 1}$ & $\mathbf{1 9 9 1}$ & $\mathbf{2 0 0 3}$ \\
\cline { 2 - 7 } & \multicolumn{7}{|c|}{ Number of population } \\
\hline Total & 100 & 100 & 100 & 100 & 100 & 100 \\
\hline $\mathbf{0 - 1 4}$ & 35.5 & 36.4 & 32.1 & 27.6 & 25.5 & 21.0 \\
\hline $\mathbf{1 5 - 6 4}$ & 57.1 & 56.5 & 60.2 & 64.2 & 66.2 & 67.0 \\
\hline $\mathbf{6 5}+$ & 7.4 & 7.1 & 7.7 & 8.3 & 8.3 & 12.0 \\
\hline $\mathbf{8 0}+$ & 1.4 & 1.5 & 1.6 & 1.6 & 1.8 & 1.6 \\
\hline
\end{tabular}

Source: Calculation of the corresponding author according to the data from the table 4

If we observe the results in Table 5, in absolute numbers, it can be seen that at the time the census from 1961 was carried out, there were 33,440 people aged of 65 and 171,658 under the age of 15 . However, according to the census from 2003 the number of elderly people doubled and accounted to 75,156 ; while the number of young people reduced to 131,883 . The data in Table 5. indicate that the Montenegrin population was affected by demographic aging. Namely, the data show that in the period 1961-2003, proportion of population of the age of 65 and over increased from $7.1 \%$ to $12 \%$, while the proportion of young people decreased from $36.4 \%$ to $21 \%$.

Table 6. Average age of the population in Montenegro, 1953-2003

\begin{tabular}{|c|c|c|c|c|c|c|}
\hline \multirow{3}{*}{ Average age } & $\mathbf{1 9 5 3}$ & $\mathbf{1 9 6 1}$ & $\mathbf{1 9 7 1}$ & $\mathbf{1 9 8 1}$ & $\mathbf{1 9 9 1}$ & $\mathbf{2 0 0 3}$ \\
\cline { 2 - 8 } & \multicolumn{6}{|c|}{ Number of population } \\
\cline { 2 - 7 } & 27.4 & 27.5 & 28.9 & 30.7 & 32.7 & 35.8 \\
\hline
\end{tabular}

Source: MONSTAT, 2008

In the period from 1961 to 2003, the average age of the population of Montenegro increased by 8.3 years (from 27.5 to 35.8). In the period 1991-2003 intensity of aging increased in 2003. The average age was 35.8. The previous analysis suggests that the aging process in Montenegro was very fast. However, in the early $21^{\text {st }}$ century, the population of Montenegro has still been considered as the group of younger demographic of European populations. In 2003, only five countries had lower average age of the population of Montenegro: Iceland, Ireland, Macedonia, Moldavia and Albania (Demographic changes in Montenegro since the mid-20 $0^{\text {th }}$ century and perspectives to 2050). Problems of age structure are presented in the European Union where there is such a relationship that one farmer younger than 35 "goes" per nine farmers over the age of 55. Some Member States (Portugal, Bulgaria, Italy, Cyprus, and the United Kingdom) have a very low percentage of young farmers, and one young farmer barely goes per 20 elderly farmers. Unfavourable demographic changes are reflected on the development of agriculture in Montenegro. There has been a sharp decline in the participation of the agricultural population in the total population of Montenegro. In period after the World War II, villages in Montenegro had suffered tremendous changes. They were the consequence of industrialization, migration and implemented measures of agrarian reform. A series of measures was adopted, and the most important regulations were regarding the reorganization of 
peasant cooperatives (30 ${ }^{\text {th }}$ March 1953), the regulations of the land fund and allocation of land ownership in agricultural organizations (May 27 ${ }^{\text {th }} 1953$ ) and the regulations on transport of land and facilities (15 th June 1954). Among other things, this legislation introduced and maximum of arable land of 10 ha per an individual farmer, and only exceptionally, in terms of the family cooperative, this property could be up to $15 \mathrm{ha}$. The age structure of a population can significantly affect consumer ethnocentric tendencies. The statistical analysis was made regardless the gender of a consumer who, expressing high ethnocentric tendencies, would be older, less educated, with low income, highly religious and dissatisfied with life in Croatia, (Matić, 2013). Table 7. shows the change of the participation of agricultural populations in the total population of Montenegro

Table 7. Change of the participation of agricultural populations in the total population of Montenegro, $1948-2003$ (\%)

\begin{tabular}{|c|c|c|c|c|c|c|}
\hline Year & 1948 & 1961 & 1971 & 1981 & 1991 & 2003 \\
\hline $\begin{array}{c}\text { Participation of } \\
\text { agricultural population in } \\
\text { total population }\end{array}$ & 75.40 & 48.0 & 42.60 & 13.00 & 7.10 & 5.30 \\
\hline
\end{tabular}

Source: Andrijašević, Rastoder,2006.

The data on the change of the participation of the agricultural population in the total population of Montenegro indicate its significant reduction in the reporting period. After 1945, as a result of the overall economic development and industrialization of the country, agricultural and general population in the mountainous area is reduced due to mass migration, so in 1961 it accounts to about $60 \%$ of the total population (Marković, 1974). The process of increasing of non-agricultural and decreasing of agricultural population was also followed by the process of enlargement of urban and reduction of rural population. In comparison to the other republics of the former Yugoslavia, Montenegro in the period 1953-1971, recorded the highest growth of the urban population in relative terms (Vujošević, 1990).

A sudden decrease in the participation of the agricultural population in the total population of Montenegro, at the same time it did not mean rapid increase in the active population. On the contrary, the percentage was very low throughout the post-war period and in 1953 it was $35.9 \%$ compared to the total population, or $65 \%$ compared to the population of working age.

Similar changes were present in other areas. Thus, for example participation of the agricultural population in the total population of Serbia was $72.10 \%$ according to the census from 1948 , while according to the census from 2002; the percentage was only $10.9 \%$. For comparison it should be noted that Sweden needed 70 years in order to decrease participation in the total agricultural population from $71 \%$ to $41 \%$ (from 1840 to 1910). In the United States of America it took 90 years (1820 were $72 \%$ of the farmers, and in 1910 there were $32 \%$ ), and Japan only after 73 years reduced participation of the agricultural population from $78 \%$ (1887) to $33 \%$ (1960). France needed 90 years to reduce the number of farmers, because in 1866 it had a participation of 63\% and 23\% in 1951 (Pejanović, 2010). 
The above described processes can be called deagrarisation of the society in Montenegro. They have contributed to the slowdown in agricultural production and the formation of an unfavourable environment for its improvement. One of the greatest consequences of deagrarisation is lack of labour force. The Montenegrin agriculture is characterized by aging of the rural population and significantly lower average level of education. More than $44 \%$ of them are older than 55 years, $65 \%$ are older than 45 . More than half $(55.3 \%)$ employed in agriculture had finished high school, and only 9.1\% had completed higher school or university (Agricultural Census, 2010, Structure of agricultural holdings, 2011b). (Graph 3.) shows labour force on family holdings, according to age.

Graph 3. Labour force family agriculture holdings

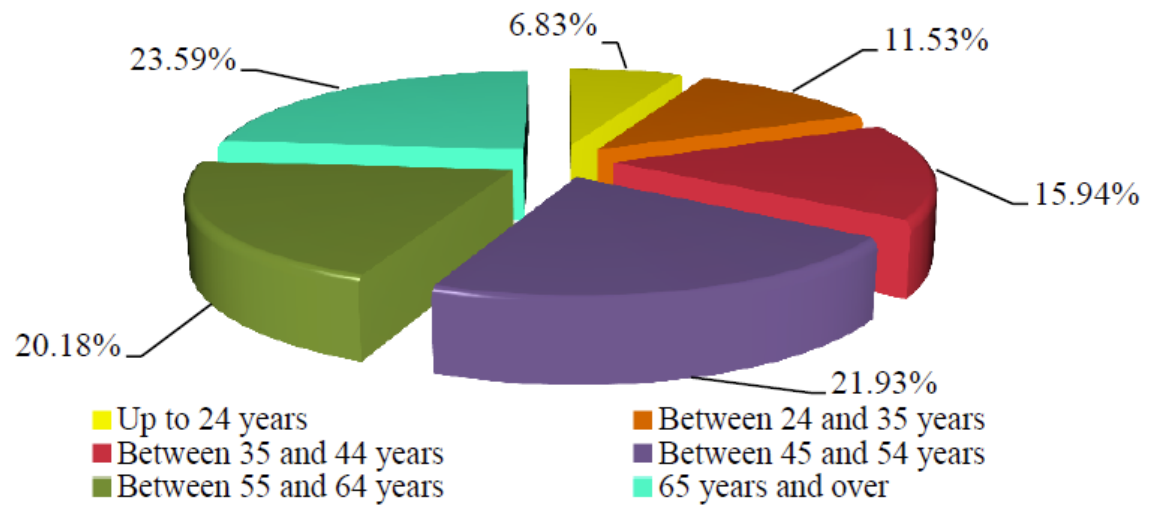

Source: Agricultural Census 2010, Structure of agricultural holdings by municipalities

Changes of unfavourable age structure of labour force in agriculture are occured even in the EU. Thus, e.g. 33\% of the labour force in agriculture is under the age of $40,57 \%$ between 40 and 65, and 10\% are 65 or over (EU Agricultural Economics Report, 2013). The unfavourable demographic changes have influenced on the under-use of agricultural land (Nejamšić, 2012). Agricultural land in Montenegro covers the area of 515,740 ha (Statistical Yearbook, 2012), which represents $37.4 \%$ of the territory of Montenegro. 189,144 ha or $36.76 \%$ of the total area is arable land. However, two-thirds of the agricultural land are currently not being cultivated. Ministry of Agriculture and Rural Development of Montenegro has launched an initiative for the lease of state-owned agricultural land to interested entrepreneurs. It is important to note that Montenegro has enough land resources for competitive production, but they are not properly distributed and used. Specifically, coastal region reports the growth in population structure, i.e. the size of household is the least favourable, while the northern region, which records decrease in the number of population, has the highest percentage of households that use larger areas of agricultural land.

Despite significant land resources, it should be noted that about $31.6 \%$ of the total agricultural land is consisted of parcels of 0.50 ha. More than half of the households $(54.1 \%)$ use 0.10 to 1 ha of agricultural land. Agricultural land is owned by family agricultural holdings and it is almost at the level of $95.2 \%$. The average agricultural holding has 4,6 ha of used 
agricultural land (Census of Agriculture, 2010). Great number of uncultivated land is due to a large participation of pasture in the total area of agricultural land in Montenegro. In the upcoming period it is necessary to work on improving living conditions in rural areas and stimulate economic activities, which will have a stimulating effect on the return of young people. It is necessary to work on harmonization of territorial development of rural areas. This can be achieved by measures which will be focused on the development of the rural economy, as well as the opening of new jobs and improving the quality of life in rural areas.

\section{Conclusion}

Decrease in population and depopulation of certain areas were one of the dominant demographic processes in Montenegro in the period from 1948 to 2011. An example of Montenegro, in this respect, was not isolated. Processes of leaving the rural areas also occurred in other countries of the former Yugoslavia. Thus, e.g. in Croatia between 1961 and 1971, more than half a million people left the rural areas. The population of Montenegro is in a phase of demographic aging. Namely, in the period 1961-2003 participation of population age of 65 and over increased from $7.1 \%$ to $12 \%$, while the proportion of young people decreased from $36.4 \%$ to $21 \%$. The unfavourable demographic changes are reflected on the development of agriculture in Montenegro. There has been a sharp decline in the participation of the agricultural population in the total population of Montenegro, which also did not mean the rapid increase of the active population. On the contrary, the percentage was very low throughout the post-war period and in 1953 it was $35.9 \%$ compared to the total population, or $65 \%$ compared to the population of working age. It is expressed a participation of population older than 65 , which makes $23.58 \%$ of the total labour force, while the participation of people under 24 makes $6.83 \%$ of the total labour force.

Montenegrin agriculture is characterized by the aging of the rural population and significantly lower average level of education. More than $44 \%$ of them are older than $55,65 \%$ are older than 45. More than half (55.3\%) employed in agriculture had finished high school, and only $9.1 \%$ had completed higher school or faculty. Despite significant land resources, it should be noted that about $31.6 \%$ of the total agricultural land is consisted of parcels area of 0.50 ha. More than half of the households (54.1\%) used 0.10 to 1 ha of agricultural land. Agricultural land is owned family agricultural holdings and it is almost at the level of $95.2 \%$. The average agricultural household has 4,6 ha of used agricultural land (Census of Agriculture, 2010). Great number of uncultivated land is due to a large participation of pasture in the total area of agricultural land in Montenegro.

In the upcoming period it is necessary to work on the improvement of living conditions in rural areas and to stimulate economic activities, which will have an incentive effect on the return of young people. It is necessary to work on harmonization of territorial development of rural areas. This can be achieved by measures which will be focused on the development of the rural economy, as well as the creation of new jobs and improving the quality of life in rural areas. 


\section{Literature}

1. Andrijašević, Ž., Rastoder, W. (2006): History of Montenegro from the ancient times to 2003, the Center for Emigrants from Montenegro, Podgorica.

2. Bandin, S. (2011): Possibilities of Socio-Economic Integration of Rural Youth in Rural Development Process, Agricultural Economics, Belgrade, Serbia, Vol. 58, No 2, pp. 207.

3. Montenegrin Academy of Science and art (MASA), (2010): Montenegro in the XXI century in the era of competitiveness, population aspects, MAS, Podgorica, Montenegro.

4. Cvijić,J.(1966):BalkanPeninsulaandSouthSlavic countries, BasisofAnthropogeography, Book, Belgrade: Institute for textbook publishing of the Social Republic of Serbia, pp. 393-394

5. Čikić, J. (2012): Educational Capital of the Rural Population in Serbia, Agricultural Economics, Novi Sad, No 53-54, pp. 53

6. European Commission (2013): Agriculture in the European Union, Statistical and economic information, (available at: http://ec.europa.eu/agriculture/statistics/ agricultural/2013/index en.htm).

7. Joksimović, M. (2014): Insurance in agriculture Montenegro in the function to minimize the risks - Master's Thesis, Faculty of Agriculture, Belgrade, p. 69.

8. Marković, P. (1974): Changes in economic and social structure of the population and labour force of mountainous regions of Yugoslavia, Agriculture and Forestry, Titograd, vol. 20, no. 4, pp. 89.

9. Mendras, H. (1986): Peasant Society: Elements for a Theory of the Peasantry, Globus, Zagreb, pp. 62-65.

10.Matić, M. (2013): The impact of demographic and socio-psychological factors on consumers'ethnocentric tendencies in Croatia, Economic research, Pula, vol. 26, no. 3, pp. 1.

11. Nejamšić, I. (2012): The effects of future demographic changes in Croatia, Acta Geographica, Zagreb, Volume 38, pp. 10.

12. Pejanović, R. (2010): Demographic problems as limiting factors for rural development of AP Vojvodina, Bulletin of the Anthropological Society of Serbia, Novi Sad, Vol. 45, pp. 65-72.

13. Statistical Office of Montenegro (MONSTAT), (2014): Perspective of population of Montenegro until 2060, with the structural analysis of the population of Montenegro, MONSATAT, Podgorica, Montenegro, (available at: http://www.monstat.org/userfiles/ file/publikacije/Demografska $\% 20$ analiza $\% 20-020 \mathrm{za} \% 20$ sajt $\% 2028 \% 20 \% 20$ mart.pdf).

14. Statistical Office of Montenegro - MONSTAT (2008): Demographic changes in Montenegro since the mid-20th century and perspective until 2050, Podgorica, Montenegro.

15. Statistical Office of Montenegro - MONSTAT (2011): Agricultural Census 2010, The structure of agricultural holdings, land used, Podgorica, Montenegro.

16. Statistical Office of Montenegro - MONSTAT (2011b): Agricultural Census 2010, The 
structure of agricultural holdings, Used land Podgorica, Montenegro.

17. Statistical Office of Montenegro - MONSTAT(2012): Statistical Yearbook of Montenegro, Podgorica, Montenegro.

18. Vujošević, N. (1990): Changes in the rural family in Montenegro, SANU, BelgradeNikšić, Book DLXXXVII, pp. 92-95.

19. Šobot, A. (2012): Three demographic consequences of gender-specific behaviour models in the case of Serbia, Population, Demographic Research Centre, Belgrade, pp. 3.

20. World Bank (WB), (2014): World Development Indicators, (available at: http://data. worldbank.org/sites/default/files/wdi-2014-book.pdf). 